\title{
Efficiency Evaluation of Anti-corrosion Treatment of Carbon Steel by Extracts of Red Algae Collected from Mediterranean Coast
}

\author{
FAIZA KHOUKHI ${ }^{1}$, SALIMA KEBBOUCHE-GANA ${ }^{2}$, NACER EDDINE DJELALI ${ }^{3 *}$, \\ MOHAMED LAMINE GANA ${ }^{1}$, RABAH BOUKHALFA ${ }^{4}$, TAMAZOUZT AIT HAMOUDA ${ }^{4}$, \\ AHLAM LOUFAR ${ }^{4}$ \\ ${ }^{1}$ Laboratory of Electrochemical Corrosion and Metallurgy Technologies \& Development Division, Sonatrach Oil and Natural \\ Gas Company, Algeria \\ ${ }^{2}$ Laboratory of VALCOR, Department of biology, Faculty of Sciences, University of M'hamed Bougara, Boumerdes, Algeria \\ ${ }^{3}$ Treatments and Formatting of the Polymers Laboratory, Faculty of Technology University of M'hamed Bougara, \\ Boumerdes, Algeria \\ ${ }^{4}$ Department of biology, Faculty of Sciences, University of M'hamed Bougara, Boumerdes, Algeria
}

\begin{abstract}
The paper presents the assessment of inhibition effectiveness of biomolecules extracted from red seaweed against biocorrosion in the petroleum industry. The first objective of this study was to obtain extracts ( $A, B$ and $C$, prepared respectively from red algae species: Corallina ellongata, Gymnogongrus crenulatus and Pterocladia capillacea) by ethanol extraction method. The infrared spectra of the three extracts confirmed the presence of amine derivatives molecules known by their anticorrosion inhibiting powers. The second objective was based on the identification of physico-chemical characteristics of the extracts and thus revealing their inhibitory and/or bactericidal power in bacterial corrosion of carbon steel in injection water contaminated with sulfato-reducing bacteria. Biological test of all extracts gave a concentration upto 10 germs $/ \mathrm{mL}$ in contaminated water by sulfato-reducing bacteria during 28 days of incubation at $37^{\circ} \mathrm{C}$. Evolution in time of the open-circuit potential showed a longer incubation time for electrolyte with extracts, whereas the stabilization time was shorter. Current corrosion density, polarization resistance, charge transfer resistance and double layer capacity were determined by using linear polarizarion resistance technique and electrochemical impedance spectroscopy. The corrosion protection efficiency of extract obtained from Gymnogongrus crenulatus (extract $B$ ) reached a maximum protective capacity of $99.69 \%$ at 5 ppm in the injection water.
\end{abstract}

Keywords: biocorrosion, inhibition, red algae, corrosive sulfato-reducing bacteria, electrochemical techniques

\section{Introduction}

The degradation of metals under the influence of microorganisms, called biocorrosion, has significant repercussions on the environment and on economy in various industrial fields, notably the oil industry [1]. The materials used in petroleum field in contact with a wet environment are liable to be corroded because of presence of microorganisms, mainly sulfato-reducing bacteria SRB, which are the main cause of anaerobic corrosion by producing hydrogen sulfide $\left(\mathrm{H}_{2} \mathrm{~S}\right)$ corrosive metabolite [2] Certainly, in order to maintain pressure oil reservoir, it is necessary to apply a system making it possible to compensate for oil's volume extracted, this being the injection water. The physicochemical composition and the nutrient richness of this water present an environment favorable to microorganism's proliferation, in particular corrosive bacteria that adhere strongly to metallic surfaces forming a biofilm.

Various treatments have been carried out to combat metallic structures degradation (corrosion) and to preserve petroleum installations with disadvantages of the use of inhibitors (using inhibitors containing toxic compounds such as chromium and nitrites) use as much as inhibitors of complicated corrosion [3-5].

\footnotetext{
*email:n.djelali@univ-boumerdes.dz
} 
Algae are groups of globally distributed photosynthetic organisms, usually aquatic or alive in wetlands According to their pigments and other morphological and physiological characteristics, several classes of algae can be distinguished: brown algae, green algae (Chlorophyceae) and red algae (Rhodophyceae) [6]. Red algae are present in fresh water but mostly are marine, they are found in particular on the tropical and subtropical coasts. Their colors diverge from blackish to multiple shades of red; these tints arise from the presence of red phycoerythrin protein or blue Pyocyanin that masks chlorophyll [7,8]. In this study, we used three algae harvested in the Zemmouri el Bahri and Dellys regions of Boumerdes on the eastern Algerian coast in Mediterranean waters. One is Corallina ellongata (syn. Corallina mediterranea or Ellisolandia elongata) from Corallinaceae family, an autotrophic marine red alga which inhabits light rocks (photopile species) in calm water and is very tolerant to pollution (opportunistic species) [9]. The second alga, Gymnogongrus crenulatus from Phyllophoraceae family, is hung on rocks generally in shallow water [9]. The third alga is Pterocladia capillacea from Pterocladiaceae family, an autotrophic red-black alga that develops in the superficial rock faults of the infralittoral stage in dark, calm, semi-slaughtered mediterranean and atlantic environments [10]. The main objective of this work is to study inhibitory effect of three natural products extracted from marine red algae on biocorrosion of carbon steel immersed in injection water contaminated by SRB as well as identification of protective films formed on carbon steel surface by several electrochemical techniques: open-circuit potential (OCP) in time, linear polarization resistance (LPR) technique and electrochemical impedance spectroscopy (EIS).

\section{Materials and methods}

\subsection{Preparation of biological material}

Red algae were collected in various regions; Dellys (Latitude 36.9158, Longitude 3.9131) and Zemmouri El Bahri coast (Latitude 36.8025, Longitude 3.56699) on December 2015 (Figure 1). Red algae collecting were carried out in places rich in algae, clinging to rocks located from 3 to $6 \mathrm{~m}$ at the seashore and $20 \mathrm{~cm}$ to one meter deep. $500 \mathrm{~g}$ of the samples are dried in the open air at an ambient temperature for one month and then crushed using an electric grinder and stored in brown glass jars protected from light and moisture.

\subsection{Characterization and extracting plant active material}

The extraction of essential oils from marine red algae was carried out using an organic solvent, ethanol, therefore an "ethanol extraction" was made. The red algae collected were ground until powders were obtained. Ethanolic extract of algae was prepared by maceration under a ventilated hood, $90 \mathrm{~g}$ of red powder and $180 \mathrm{~mL}$ of ethanol are introduced into a $250 \mathrm{~mL}$ Erlenmeyer flask [11]. The flask was then closed to avoid evaporation of the solvent, and then continuously stirred at an average speed for three successive days (72 h), at ambient temperature. After stirring, the macerate was filtered through a funnel, where a compress was first placed, through a filter paper. Figure 1 summarizes the various extraction steps already mentioned.

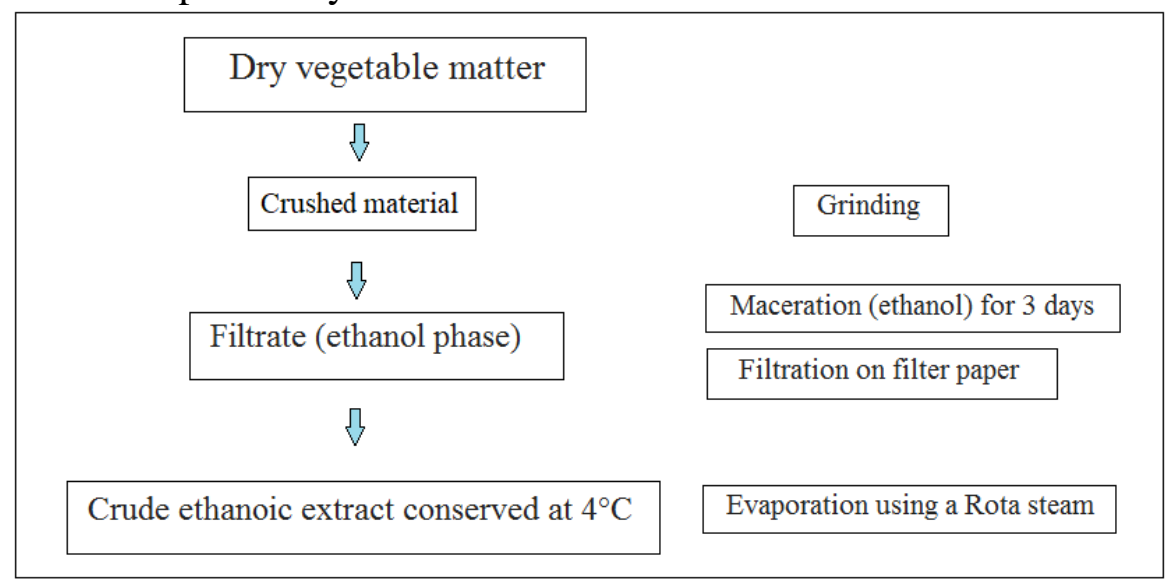

Figure 1. Steps for obtaining ethanoic crude extract 
After that, we determined the organoleptic and physicochemical properties $(p \mathrm{H}$, density, viscosity, appearance, color and odor) of ethanolic extracts. Analysis by infrared spectroscopy made it possible to identify the active biomolecules constituting the three extracts using a spectrometer (Shimadzu 8900 type FTIR spectrometer).

The sample of injection water used for this study comes from the oilfield of Rhoude El Baguel located $70 \mathrm{~km}$ from east of Hassi Messaoud in the south of Algeria.

\subsection{Efficiency tests of bionatural extracts $A, B$ and $C$ on growth of SRB by microbiological method}

For evidencing the inhibitory effect, three representative algae extracts were prepared: A (from Corallina ellongata), B (from Gymnogongrus crenulatus) and $\mathbf{C}$ (from Pterocladia capillacea). The sample of injection water used for this study comes from the oilfield of Rhoude El Baguel located 70 $\mathrm{km}$ from east of Hassi Messaoud in the south of Algeria. Seven sets of five penicillin vials containing Postgate's SRB culture media and decimal dilutions of injection water were incubated for $48 \mathrm{~h}$. After autoclaving, the first set of five was considered than control, and the remaining six series will serve as an inoculum for the efficacy trials of extracts extract s A, B and C obtained from the marine red algae. In order to evaluate the efficiency of these, two concentrations of the extracts $\mathrm{A}, \mathrm{B}$ and $\mathrm{C}$ were injected into the penicillin vials prepared previously and then incubated at $37^{\circ} \mathrm{C}$ for 28 days. The results are expressed throughout the incubation period. During the visual examination of the vials, two cases occur; first case: Positive vial shift from staining to black (synthesis of $\mathrm{H}_{2} \mathrm{~S}$ by SRB); ineffective extract and the second case: Negative bottle not blackening the extract is effective.

\subsection{Inhibition efficiency test of bionatural extracts by weight loss method}

To demonstrate the bactericidal efficacy of the three seaweed extracts, we carried out a test for the evaluation of the bacterial corrosion rate by weight loss method [12,13]. After polishing carbon steel coupon's area of $1.44 \mathrm{~cm}^{2}$, the steel samples were immersed in injection water inoculated with SRB (10\%). Bottles are placed in an incubator for $48 \mathrm{~h}$ and then $15 \mathrm{ppm}$ of each extract was injected into the first three flasks and the fourth is considered as a control. The duration of exposure was 45 days. All weighings were performed with analytical balance (KERN). and were done using method of weight loss norm (RP 0775-99 - corrosion coupons installation and handling). This method is based on the calculation of the rate of corrosion with respect to the difference in weight of steel before and after its exposure in a corrosive medium during 45 days, based on the equation:

$$
V_{\text {corr }}=(\Delta \mathbf{P} / \text { t.p.S })
$$

where: $\mathrm{V}_{\text {corr: }}$ corrosion rate, $\Delta \mathrm{P}=\mathrm{P}_{\mathrm{f}}-\mathrm{P}_{\mathrm{i}}$ is weight loss, $\mathrm{t}$ : exposure time of the steel coupon (it was considered the number of $8760 \mathrm{~h}$ in a year), $\rho$ : density of carbon steel $\left(7.86 \mathrm{~g} / \mathrm{cm}^{3}\right), \mathrm{S}$ : surface area of the corroded coupon.

The steel coupons are then observed using a scanning electron microscope (MEB-QUANTA 650) and a metallurgical microscope (Olympus PMG3).

\subsection{Inhibition efficiency test of bionatural extracts by electrochemical method}

The electrochemical equipment used in this study is composed of a potentiostat /galvanostat (Type EGEG Princeton Applied Research, model 273A), that makes it possible to impose and measure stable potentials and currents in cathodic and anodic domains (Electrometer; Type EGG, model 273A), Frequency analyzer of Solarton type (model SI 1255) for electrochemical impedance measurement. Nitrogen generator equipped with a pressure regulator with an inlet pressure of 300 bars and an outlet pressure adjustable between 1 and 12 bars, computer equipment connected to the potentiostat /galvanostat equipped with data acquisition, and processing software, making it possible to plot the various curves and to calculate the electrochemical parameters (Software 352 SoftCorrIII), for stationary methods and 
Software Z plot, Z view, for electrochemical impedance spectroscopy and electrochemical cell, composed of Pyrex glass of volume $1000 \mathrm{~mL}$, provided with five orifices for carrying the following accessories: A working electrode; A saturated calomel reference electrode (SCE); A glass gas bubbler; Two counter-electrodes in graphite $6 \mathrm{~mm}$ in diameter and $30 \mathrm{~cm}$ in length.

A volume of $700 \mathrm{~mL}$ of the injection was placed on an electrochemical cell made of Pyrex glass. The graphite electrodes were placed in the electrochemical cell, the other orifices were sealed. The cell was bubbled with nitrogen for $30 \mathrm{~min}$ in order to exclude all the air from the test solution and then autoclaved at $120^{\circ} \mathrm{C}$ for $20 \mathrm{~min}$ at $1 \mathrm{bar}$. In front of a Bunsen spout, inoculation of the electrochemical cell with $5 \%$ BSR of $10^{6}$ germs $/ \mathrm{mL}$ concentration was carried out, a reference electrode SCE (saturated calomel electrode) was introduced, and finally the carbon steel working electrode of API 5L Grade X60 type (Table 1) was immersed in the mixture after being polished and rinsed with acetone.

Table 1. Chemical composition of carbon steel (API 51 x60)

\begin{tabular}{|c|c|c|c|c|c|c|c|c|c|c|}
\hline ELEMENT \% & $\mathbf{C}$ & $\mathbf{S i}$ & $\mathbf{M n}$ & $\mathbf{N i}$ & $\mathbf{C r}$ & $\mathbf{P}$ & $\mathbf{S}$ & $\mathbf{M o}$ & $\mathbf{C u}$ & $\mathbf{F e}$ \\
\hline API 5L X60 & 0.22 & 0.23 & 1.31 & 0.044 & 0.05 & 0.013 & 0.01 & 0.016 & 0.06 & 98.047 \\
\hline
\end{tabular}

The bionatural extracts $\mathrm{A}, \mathrm{B}$ and $\mathrm{C}$ at different concentrations then were treated the solution (5ppm, $10 \mathrm{ppm}, 15 \mathrm{ppm}, 20 \mathrm{ppm}, 30 \mathrm{ppm}, 50 \mathrm{ppm}$ ). The curves of the different techniques such as the open -circuit potential (OCP) vs. - time, linear polarization resistance curves (LPR) and electrochemical impedance spectra (EIS) were recorded. Open circuit potential OCP $\pm 30 \mathrm{mV}$ for potential region, potential scan rate of $0.166 \mathrm{mV} / \mathrm{s}$ and EIS sinusoidal voltage of $10 \mathrm{mV}$ applied with frequency domain from $100 \mathrm{KHz}$ to $10 \mathrm{mHz}$ were used.

Values of polarization resistance $\mathrm{R}_{\mathrm{P}}$, corrosion current density $\mathrm{I}_{\mathrm{Corr}}$, corrosion rate $\mathrm{CR}$ and inhibition efficiency $E$ were calculated by using LPR technique. Values of the ohmic resistance of solution $R_{e}$, charge transfer resistance $R_{c t}$, double layer capacity $C_{d l}$, phase angle $\theta$ and inhibition efficiency $E$ were determined using EIS diagrams as Nyquist and Bode spectra. The inhibition efficiency of the extract was calculated from the charge transfer resistance values using the following equations:

$$
E \%=\frac{R_{P o}-R_{P}}{R_{P o}} .100 \quad E \%=\frac{R_{c t o}-R_{c t}}{R_{c t o}} .100
$$

where: $R_{P o}, R_{P}$ and $R_{c t ~ o}, R_{c t}$ are the charge transfer resistance in absence and in presence of inhibitor extract, respectively.

\section{Results and discussions}

\subsection{Characterization of algae extracts and electrolyte}

The organoleptic and physicochemical analysis of the extract algae were done by examine

The appearance, viscosity, $p \mathrm{H}$, solvent solubility and water solubility as per quality standards of European pharmacopoeia are shown in Table 2 and Figure 2.

Table 2. Organoleptic and physico-chemical characteristics of organic extracts a, b and c obtained from marine red algae

\begin{tabular}{|c|c|c|c|c|c|c|c|c|}
\hline & Odor & Color & $p H$ & $\begin{array}{c}\text { Density } \\
\mathrm{g} / \mathrm{cm}^{3} \\
\text { at } 20^{\circ} \mathrm{C}\end{array}$ & $\begin{array}{c}\text { Viscosity } \\
\mathrm{cP}\end{array}$ & & \multicolumn{3}{|c|}{ Solubility in } \\
\cline { 6 - 9 } Extract A & $\begin{array}{c}\text { Characteristic of } \\
\text { algae }\end{array}$ & green & 6.9 & 0.831 & 1.72 & + & + & - \\
\hline
\end{tabular}




\begin{tabular}{|c|c|c|c|c|c|c|c|c|}
\hline Extract B & $\begin{array}{c}\text { Characteristic of } \\
\text { algae }\end{array}$ & dark green & 6.3 & 0.851 & 1.91 & + & + & - \\
\hline Extract C & $\begin{array}{c}\text { Characteristic of } \\
\text { algae }\end{array}$ & dark green & 6.1 & 0.866 & 2.18 & + & + & - \\
\hline
\end{tabular}

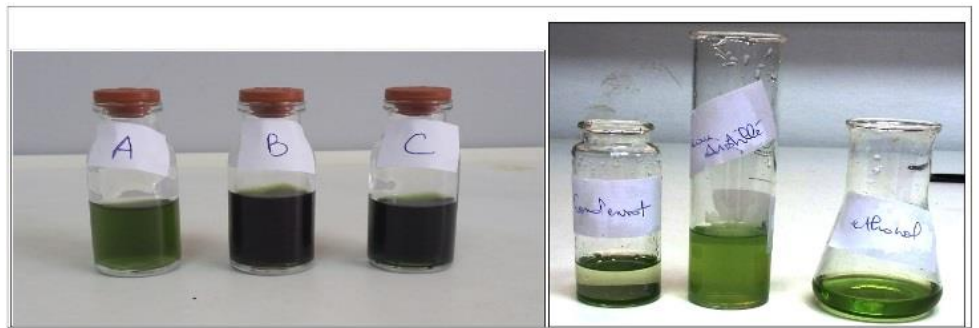

Figure 2. Aspect of three algae extracts and solubility test results

The characterization of extracts by infrared spectroscopy was made in order to know their relative chemical compositions and thus revealing the structure of the bioactive molecules that compose them. Therefore, Figure 3 shows the adsorption bands of the extracts A, B and C based on marine red algae. The identification by infrared spectroscopy shows identical spectra for three extracts A, B and C. The spectrum exhibits an intense absorption band in the region 1820-1660 $\mathrm{cm}^{-1}$ indicates the presence of carboxyl group $\mathrm{C}=\mathrm{O}$. We observed an absorption band of average intensity around 3400 and $3300 \mathrm{~cm}^{-}$ ${ }^{1}$ indicates presence of group $\mathrm{N}-\mathrm{H}$, confirms the presence of amine function in the extract. The spectrum exhibits a low intensity absorption band located at about $1650 \mathrm{~cm}^{-1}$ indicates the presence of the alkene function. This is probably the spectrum of the trimethylamine molecule, which has the formula $\left(\mathrm{C}_{3} \mathrm{H}_{9} \mathrm{~N}\right)$. Amines are very often used for the protection of parts in natural aqueous media they are considered as functional groups very effective in corrosion of ferrous metals these organic compounds capable of functioning as corrosion inhibitors contain an active center $\mathrm{N}, \mathrm{S}, \mathrm{O}, \mathrm{P}$ capable of exchanging electrons with metal [14].

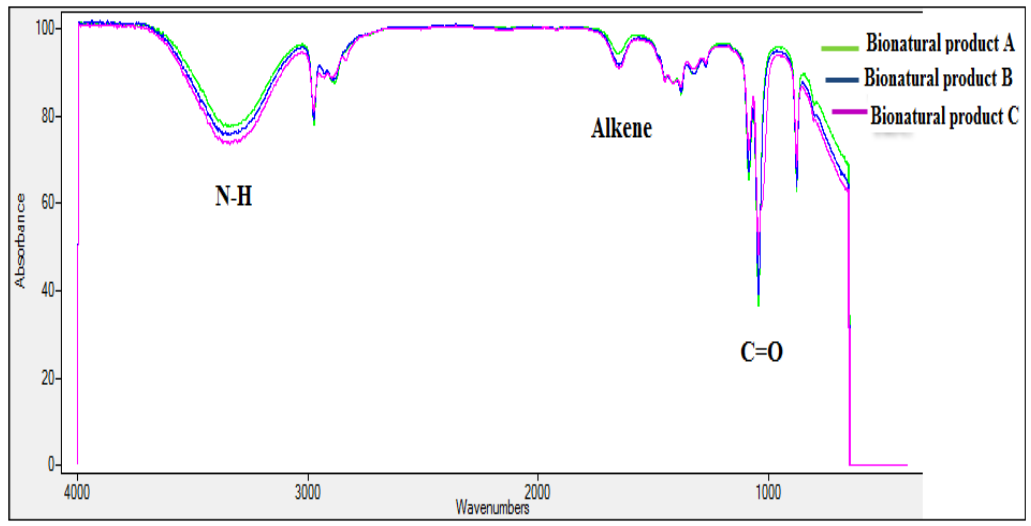

Figure 3. Infrared spectrum of three bionaturals extracts A, B and C

Injection water was obtained from the of Rhoude El Baguel oilfield. In situ, the injected water temperature is between 19 and $20^{\circ} \mathrm{C}$ and $p \mathrm{H}$ 6.9. The chemical composition of electrolytes in the injected water obtained for this study is given in Table 3. 
Table 3. Chemical composition of Rhoude El Baguel injected water

\begin{tabular}{|c|c|c|c|}
\hline \multicolumn{2}{|c|}{ Dosing elements } & \multirow{2}{*}{$\begin{array}{c}\begin{array}{c}\text { Concentratio } \\
\text { n (mg/L) }\end{array} \\
583.665 \\
\end{array}$} & \multirow{2}{*}{$\begin{array}{c}\begin{array}{c}\text { Concentration } \\
(\mathbf{m E q})\end{array} \\
29.183\end{array}$} \\
\hline \multirow{5}{*}{ Cations } & $\mathrm{Ca}^{2+}$ & & \\
\hline & $\mathrm{Mg}^{2+}$ & 112.48 & 9.25 \\
\hline & $\mathrm{Fe}^{2^{+}}$ & 14.632 & 0.524 \\
\hline & $\mathrm{Na}^{+}$ & 318.30 & 13.82 \\
\hline & $\mathrm{K}^{+}$ & 25.98 & 0.66 \\
\hline & Total & - & 53.437 \\
\hline \multirow{3}{*}{ Anions } & $\mathrm{Cl}^{-}$ & 1329.63 & 37.5 \\
\hline & $\mathrm{HCO}_{3}{ }^{2-}$ & 169.58 & 2.78 \\
\hline & $\mathrm{SO}_{4}{ }^{2-}$ & 574.48 & 11.96 \\
\hline & Total & - & 52.24 \\
\hline Salinity & $1.6 \mathrm{mg} / \mathrm{L}$ & $3.3 \mathrm{mS} / \mathrm{Cm}$ & $\mathrm{pH}$ \\
\hline
\end{tabular}

It should be noted that there is an influence of injection water's composition on SRB growth. Several authors [15-17] have mentioned the influence of physicochemical parameters on bacterial development. They stated that the growth of bacteria depends on the chemical composition of the medium, the physicochemical conditions and the specific nutrients present. Therefore the injection water studied contains nutrients (carbon, sulfur, and trace elements), which are essential to bacteria growth. Determination of mineral salts shows that injection water is salty and contains high concentration of sulfate ions, which play the role of electron acceptor [18]. In fact, sulfates also have a source of sulfur at SRB and are included in composition of two amino acids, cysteine and methionine which participate in proteins structure [19].

The presence of considerable concentration of $\mathrm{Ca}^{2+}$ and $\mathrm{Mg}^{2+}$ ions is observed; certainly, $\mathrm{Ca}^{2+}$ ions favor bacterial absorption. On the other hand, $\mathrm{Mg}^{2+}$ ions are in favor of reducing sulfates to sulfides [19]. We note that this water has a very low concentration of iron; in fact, this present -concentration comes from metal dissolution. In this regard, this element is considered an enzymatic factor [20]. Moreover, iron is part of many cytochromes structure; it also enters into basic structure of hydrogenases, the important enzymes of sulfate reduction by SRB. It should be noted that reduction of sulfate results in hydrogen sulfide $\left(\mathrm{H}_{2} \mathrm{~S}\right)$ formation, which reacts with ferrous ions $\left(\mathrm{Fe}^{2+}\right)$ of culture medium to obtain a black precipitate of iron sulfide (FeS). In our study, waters present a wide sulfate concentration. The SRB growth and their biological activity depend on sulfate concentration and the sampling water origin. In general, SRB tend to synthesize one or more metabolic products. Biochemically, SRB transform a sulfate to sulfide, a reaction which is catalyzed by adenosine phosphor-sulfate reductase.

\subsection{Efficiency evaluation of bionatural extracts by microbiological method}

In order to monitoring the efficiency of $\mathrm{A}, \mathrm{B}$, and $\mathrm{C}$ extracts on SRB growth as a function of incubation time, they were maintained at $37^{\circ} \mathrm{C}$ and over incubation period of 28 days. Before injection extracted products, a value of $10^{2}$ germs $/ \mathrm{mL}$ was obtained at the end of $14^{\text {th }}$ day of incubation at $37^{\circ} \mathrm{C}$. After injection $10 \mathrm{ppm}$ of extract $\mathrm{A}$, the concentration was zero until the $7^{\text {th }}$ day of incubation, from there SRB concentration becomes 10 germs $/ \mathrm{mL}$ up to the $28^{\text {th }}$ day.

For the extract $\mathrm{B}$ injected at $10 \mathrm{ppm}$, the contamination does not remain during the entire incubation period. So, by injecting $10 \mathrm{ppm}$ of extract $\mathrm{C}$; no contamination while 14 days and from the 15 th day it becomes equal to 10 germs $/ \mathrm{mL}$.

However, by injecting $20 \mathrm{ppm}$ of each extract into penicillin vials containing $9 \mathrm{~mL}$ of SRB contaminated injection water, extract A gave a zero concentration of bacterial germs for 14 days after which this concentration increased to 10 germs $/ \mathrm{mL}$. With extract $\mathrm{B}$, no contamination was recorded during 28 days of incubation. Moreover, by injecting extract $\mathrm{C}$, no contamination was observed for 21 days but at the end of the $22^{\text {nd }}$ day a concentration of 10 germs $/ \mathrm{mL}$ of SRB was noted. Of these results, 
we find that the extract B obtained from Gymnogongrus crenulatus is very active against SRB growth. The extract $\mathrm{C}$ from Pterocladia capillacea is active at $10 \mathrm{ppm}$. Extract A from Corallina elongata is active at $20 \mathrm{ppm}$. To confirm these results, a study of efficiency by electrochemical techniques for three extract s A, B and C was carried out.

\subsection{Efficiency evaluation of bionatural extracts on biocorrosion by metal weight loss method}

After a 45-day contact between (the steel-injection water) which underwent treatment with different concentrations of plant extracts, we obtained the results given in Table 4.

Table 4. Evaluation of corrosion rate by weight loss method as a function of the variation in the concentration of the algae extract in the injection water

\begin{tabular}{|c|c|c|c|c|c|c|}
\hline $\begin{array}{c}\text { Carbon Steel } \\
\text { API5LX60 }\end{array}$ & $\begin{array}{c}\text { Initial } \\
\text { Weight } \\
\mathrm{W}_{\mathrm{i}}(\mathrm{g})\end{array}$ & $\begin{array}{c}\text { Final } \\
\text { weight } \\
\mathrm{W}_{\mathrm{f}}(\mathrm{g})\end{array}$ & $\begin{array}{c}\Delta \mathrm{W}(\mathrm{g}) \\
(\mathrm{Wi}-\mathrm{Wf})\end{array}$ & $\begin{array}{c}\text { Exposure } \\
\text { Time } \\
(\mathrm{Days})\end{array}$ & $\begin{array}{c}\text { Corrosion } \\
\text { rate CR } \\
\mathrm{mm} / \mathrm{year}\end{array}$ & $\begin{array}{c}\text { Efficiency } \\
(\%)\end{array}$ \\
\cline { 1 - 4 } $\begin{array}{c}\text { Control sample } \\
\text { CS }\end{array}$ & 8.68 & 4.9 & $\mathbf{3 . 7 8}$ & & $\mathbf{0 . 0 0 3}$ & - \\
\cline { 1 - 3 } extractA & 9.64 & 9.58 & $\mathbf{0 . 0 6}$ & \multirow{2}{*}{45} & $\mathbf{0 . 0 0 0 0 4}$ & 98.66 \\
\hline extractB & 9.24 & 9.22 & $\mathbf{0 . 0 2}$ & & $\mathbf{0 . 0 0 0 0 1}$ & 99.66 \\
\hline extractC & 8.39 & 8.36 & $\mathbf{0 . 0 3}$ & & $\mathbf{0 . 0 0 0 0 2}$ & 99.33 \\
\hline
\end{tabular}

$\mathrm{CR}(\mathrm{mm} /$ year $)=\Delta \mathrm{W} /\left(\rho^{*}\right.$ Time*A $) * 0.365 ;\left(\rho=7.8 \mathrm{~g} / \mathrm{cm}^{3}\right) ;$ A: Coupon area $\mathrm{Cm}^{2}$

From results of Table 4, we find that corrosion rate of carbon steel in presence of SRB over a period of 45 days is high; it is $0.003 \mathrm{~mm} / \mathrm{year}$. After injection of the extract A, corrosion rate decreases and gives a protective power of $98.66 \%$. With extract $\mathrm{B}$, corrosion rate is $0.00001 \mathrm{~mm} / \mathrm{year}$, which gives a protective power of $99.66 \%$. Finally, with the injection of extract C, corrosion rate is $0.00002 \mathrm{~mm} / \mathrm{year}$ giving a protective power of $99.33 \%$. We conclude that protective power of bionatural extract $\mathrm{B}$ is higher than $\mathrm{C}$ and higher than A. The active substance extracted from red algae Gymnogongrus crenulatus has a bactericidal power over corrosion caused by SRB more active than bionatural extract from Corallina elongata and Pterocladia capillacea.

\subsection{Surface morphology analysis}

A microscopy analysis of morphology was performed using the scanning electron microscopy (SEM) and metallurgical characterization of the API 5L X60 carbon steel. Figures 4-7 show the surface after formation of the bacterial biofilm with and without treatment by the natural extracts $\mathrm{A}, \mathrm{B}$ and $\mathrm{C}$ obtained from the red algae to distinguish the formed biofilm and the protective film of the biomolecules inhibiting biocorrosion. Metallurgical observations of carbon steel coupons immersed for 45 days in contaminated injection water by SRB and treated with bionaturels extracts A, B and C show differences between treatments performed surfaces. 


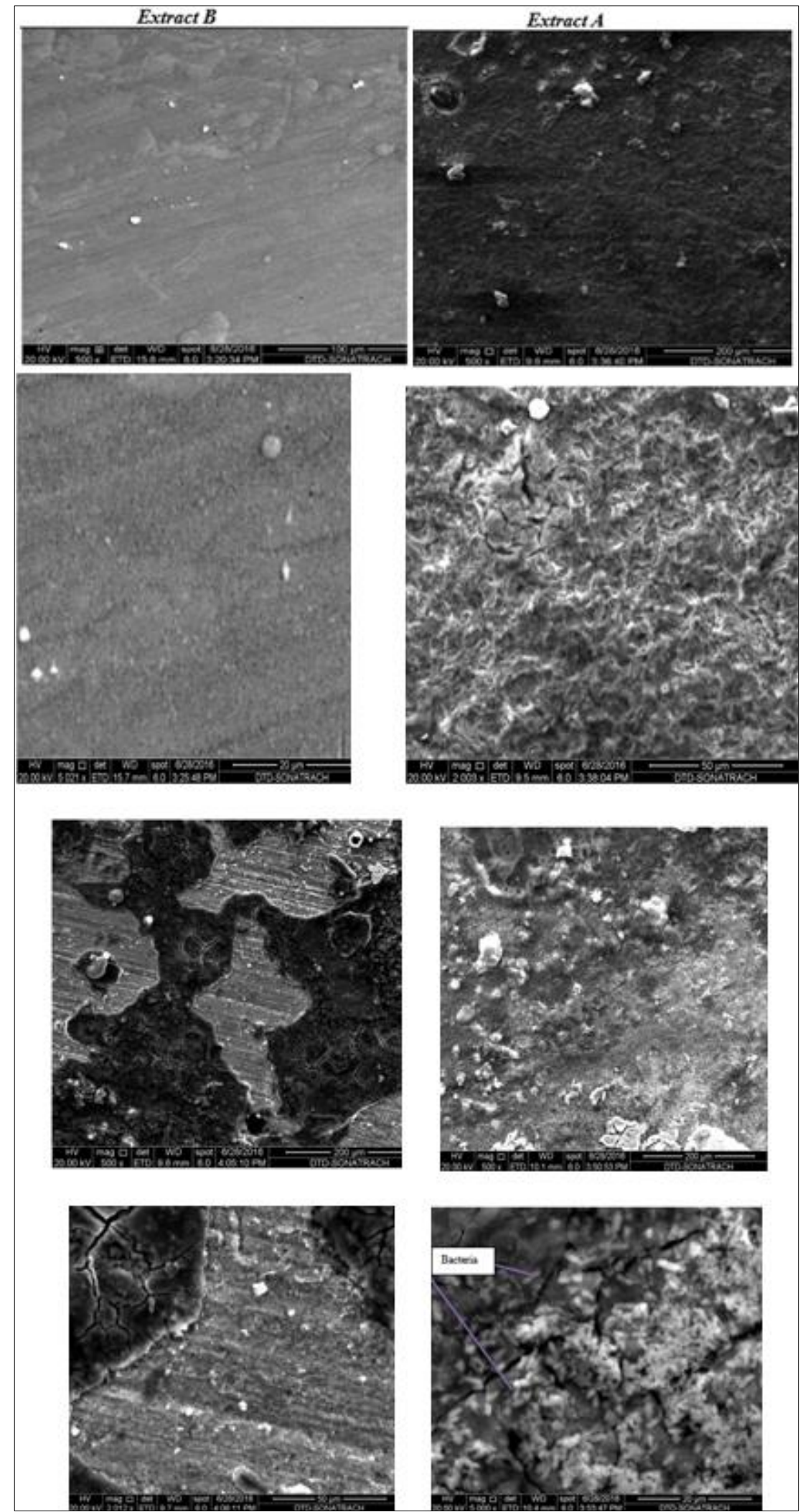

Figure 4. SEM images API 51 X60 carbon steel surface immersed for 45 days in injection water contaminated with SRB and treated with extracts $B$ of 15 ppm concentration 

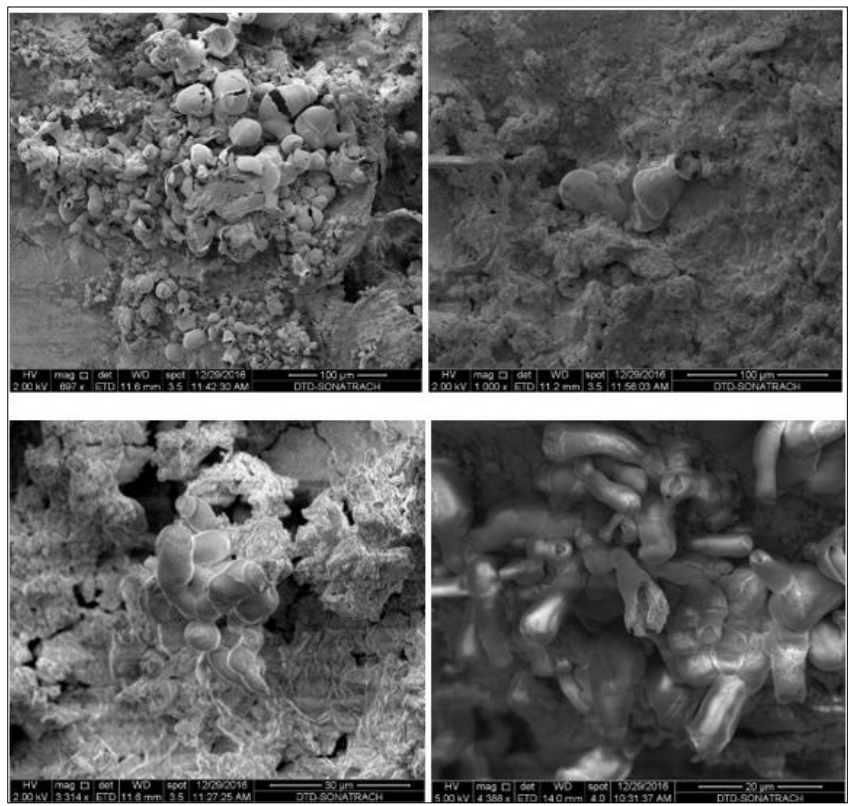

Figure 5. SEM Characterization by different magnifications of the carbon steel surface of API 5L X60 grade. Stage of formation of a bacterial Biofilm after immersion in injection water inoculated by SRB after 45 days of incubation at $37^{\circ} \mathrm{C}$
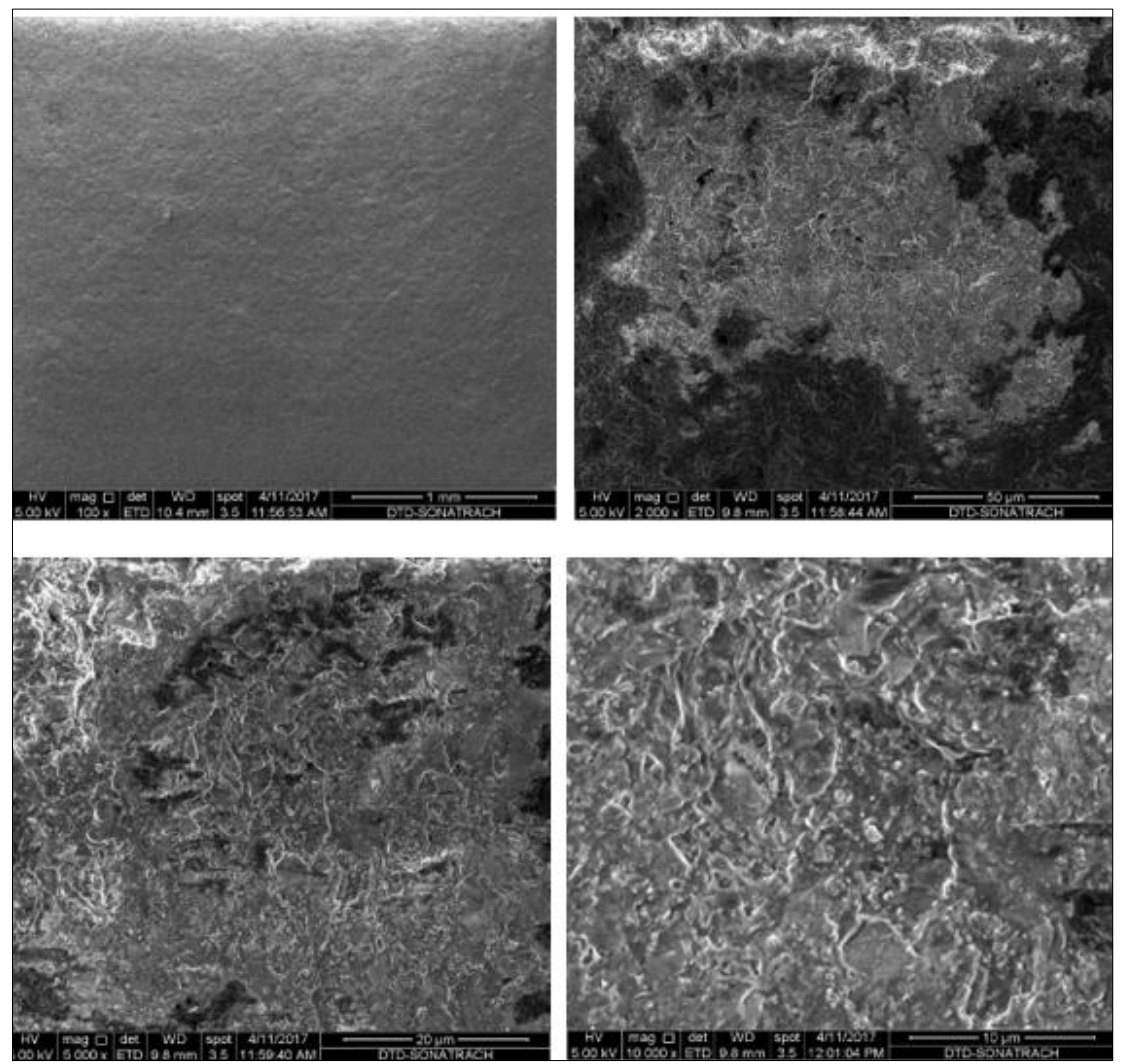

Figure 6. SEM Characterization of carbon steel surface of API 5L X60

grade at different magnifications - Step of formation of a protective film after immersion in a contaminated injection water by the SRB and treated with the extract a obtained from Corallina elongata red algae extract after 45 days of incubation at $37^{\circ} \mathrm{C}$ 


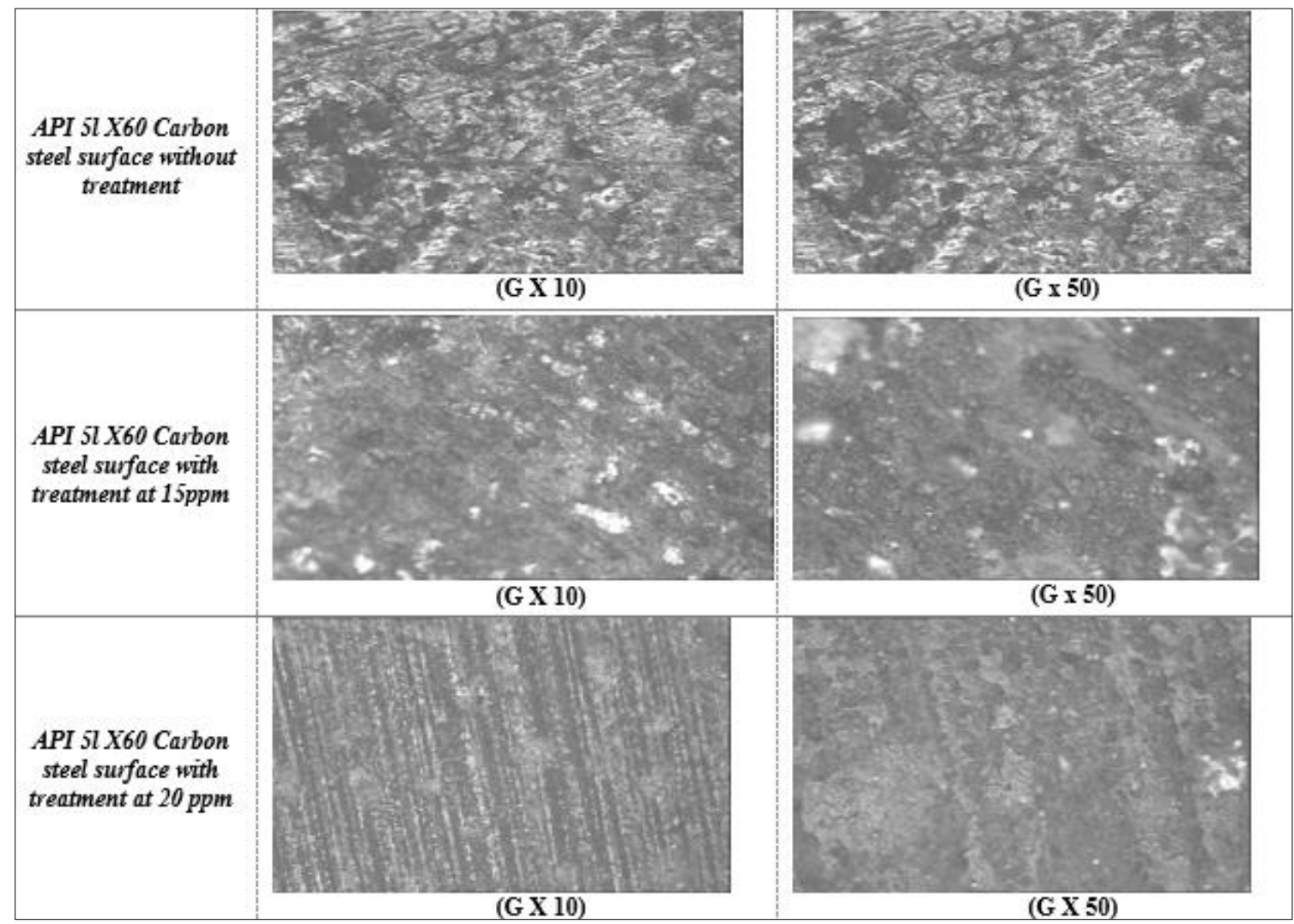

Figure 7. Metallurgical microscopy images of the coupons API 51 X60 Carbon steel surface without and with treatment after stripping the biofilm

The observation of the steel coupons with the scanning electron and metallurgical microscope shows more details. According to Figures 4-7, we noticed the presence of a biofilm formed by the sulfatoreducing bacterial consortium that covered the steel surface by the products of the bacterial metabolism formed during 45 days of immersion. Water is a changing environment where there is a trade-off between contaminated water and steel, bacterial biofilm deposit is formed on the metal surface. According to micrographics photos, SRB tend to focus on metal surfaces and associate in communities to form a biofilm. Thus, we shown that metal supports are susceptible to microbial colonization. At a concentration $15 \mathrm{ppm}$ and $20 \mathrm{ppm}$, the surface of the steel treated with the algae extract B is clear and completely clean, forms a protective layer on the metal, and prevents the development of bacterial biofilm. Extract B is more effective against corrosion by inhibiting the development of SRB.

\subsection{Efficiency evaluation of bionatural extracts on biocorrosion by electrochemical techniques}

Open-circuit potential (OCP) evolution over the time is of crucial importance. Certainly, the profile of the $\mathrm{OCP}=\mathrm{f}(\mathrm{t})$ curve gives information on the evolution of the metal surface in contact with corrosive medium. The curves of potentials obtained as a function of time for the electrodes immersed in a solution contaminated by SRB before and after treatment with bionatural extracts A, B and C are shown in Figure 8. Table 5 presents the obtained data of OCP indicating stabilization time and incubation time. 


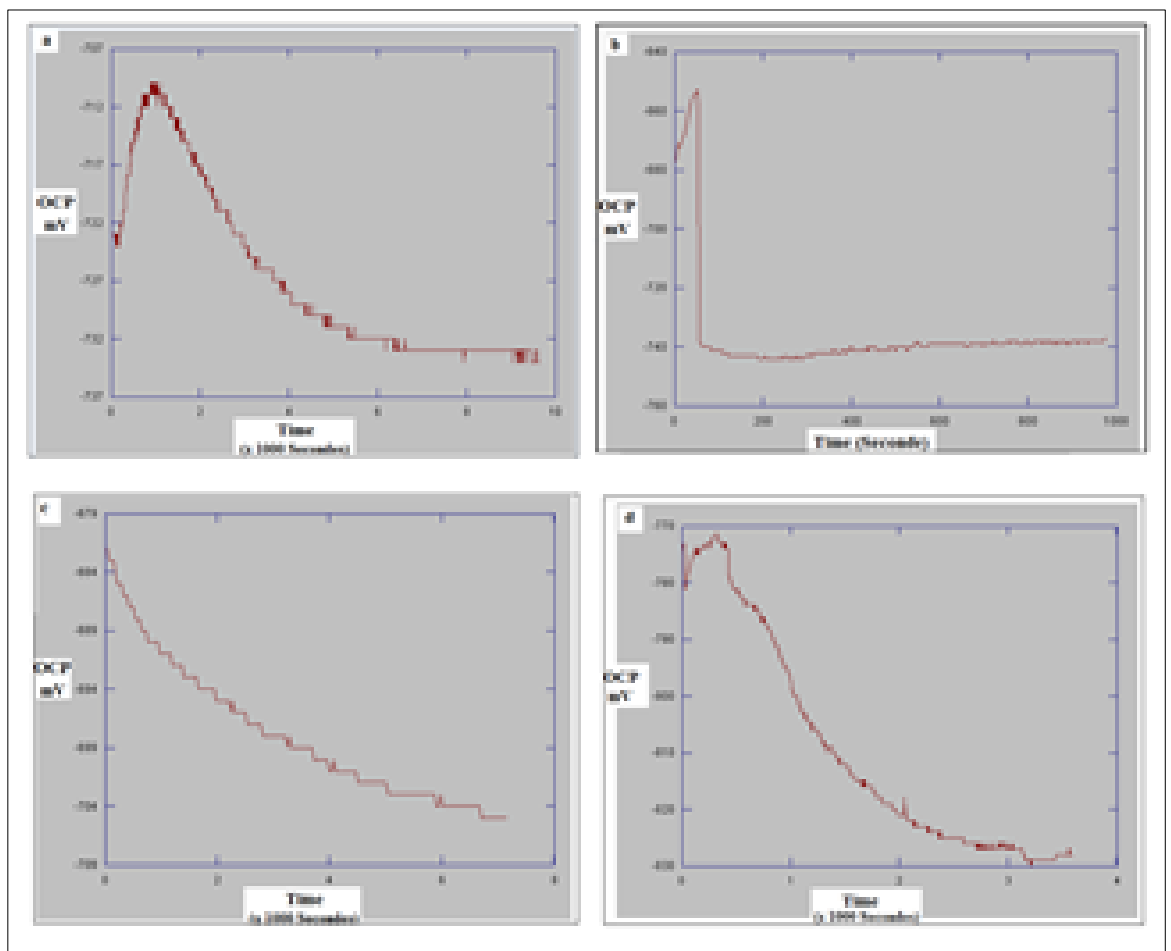

Figure 8. Open-circuit potential evolution in the first three hours of carbon steel immersed in injection water treated with bionatural extracts

$\mathrm{A}, \mathrm{B}$ and $\mathrm{C}-\boldsymbol{a}$. Control sample $-\boldsymbol{b}$. Treat by $10 \mathrm{ppm}$ of extract $\mathrm{A}$ after 5 days immersion - c. Treated by 10 ppm of extract $C$ after 12 days immersion $-\boldsymbol{d}$. Treated by 10 ppm of extract $B$ after 10 days immersion

Table 5. Open- circuit orrosion potential of carbon steel measured in injection water contaminated by SRB and treated by bionatural extracts $\mathrm{A}, \mathrm{B}$ and $\mathrm{C}$

\begin{tabular}{|c|c|c|c|}
\hline Injection water inoculated with SRB & $\begin{array}{c}\text { Incubation } \\
\text { Time (Days) }\end{array}$ & $\begin{array}{c}\text { Stabilisation } \\
\text { time (Second) }\end{array}$ & $\begin{array}{c}\text { OCP } \\
\text { V/SCE }\end{array}$ \\
\hline without treatment & 3 & 9600 & -0.735 \\
\hline treated with 10 ppm of extract A & 5 & 3600 & -0.698 \\
\hline treated with 50 ppm of extract A. & 6 & 3700 & -0.663 \\
\hline treated with 10 ppm of extract B & 10 & 3600 & -0.677 \\
\hline treated with 50 ppm of extract B & 11 & 3900 & -0.533 \\
\hline treated with 10 ppm of extract C & 12 & 3600 & -0.671 \\
\hline treated with 50 ppm of extract C & 13 & 3900 & -0.633 \\
\hline
\end{tabular}

OCP evolution gives stabilization times that differ from one electrolyte to another according to the species present in each medium (injection water, sulfate-reducing bacteria, extract A, extract B, extract C). Without treatment, OCP tends towards more negative values $(-0.735 \mathrm{~V} / \mathrm{SCE})$, indicating presence of corrosion in this area [21]. By injecting different concentrations from $10 \mathrm{ppm}$ to $50 \mathrm{ppm}$ of bionaturels extracts, OCP with extract A gives -0.698 and $-0.663 \mathrm{~V} / \mathrm{SCE}$ respectively. Indeed, OCP with extract B gives -0.677 and $-0.533 \mathrm{~V} / \mathrm{SCE}$ and with extract $\mathrm{C}$ gives -0.671 and $-0.633 \mathrm{~V} / \mathrm{SCE}$. These values tend 
towards a more noble or electropositive potential. So, we are in protection domain according to the Pourbaix diagram [21]. After potential stabilization, the system allows us to test other electrochemical techniques such as LRP and EIS test to determine the phenomena occuring at the metal/solution interface. Concerning, linear polarization resistance measurements using Resistance the bionatural extract $\mathrm{A}$, the values of polarization resistance $\mathrm{Rp}$ obtained from the slopes of straight lines electrode potential $=\mathrm{f}$ (current density) for the system (injection water and chemical species of extract A from red algae Corallina elongata at different concentrations) in contact with carbon steel are reported in Table 6. Values of corrosion current density, corrosion rate and inhibitory efficiency are also listed.

Table 6. Electrochemical parameters obtained by LRP technique of carbon steel immersed in an untreated medium and treated one with extract $\mathrm{A}$

\begin{tabular}{|c|c|c|c|c|c|}
\hline $\begin{array}{c}\text { Concentration of } \\
\text { bionatural extract A } \\
(\mathrm{ppm})\end{array}$ & $\begin{array}{c}\text { OCP } \\
(\mathrm{V} / \mathrm{SCE})\end{array}$ & $\begin{array}{c}\text { Polarization } \\
\text { resistance Rp } \\
\left(\mathrm{K} \Omega . \mathrm{cm}^{2}\right)\end{array}$ & $\begin{array}{c}\text { Corrosion } \\
\text { current } \\
\text { density Icorr } \\
\left(\mu \mathrm{A} / \mathrm{cm}^{2}\right)\end{array}$ & $\begin{array}{c}\mathrm{CR} \\
(\mathrm{mm} / \mathrm{year})\end{array}$ & $\begin{array}{c}\text { Efficiency } \\
(\%)\end{array}$ \\
\hline 0 & -0.735 & 0.205 & 105.48 & 2.088 & $/$ \\
\hline 5 & -0.698 & 1.485 & 14.62 & 0.148 & 86.20 \\
\hline 10 & -0.698 & 2.112 & 10.27 & 0.104 & 90.29 \\
\hline 15 & -0.695 & 3.125 & 06.94 & 0.070 & 93.44 \\
\hline 20 & -0.697 & 4.205 & 05.09 & 0.051 & 95.12 \\
\hline 30 & -0.682 & 6.115 & 04.79 & 0.048 & 96.65 \\
\hline 50 & -0.663 & 7.338 & 02.95 & 0.033 & 97.20 \\
\hline
\end{tabular}

From the results reported in Table 6, we find low strength of steel without treatment. We noted the value of $0.205 \mathrm{KOhm} . \mathrm{cm}^{2}$ that corresponds to $2.088 \mathrm{~mm} /$ year corrosion rate. After injection of different concentrations of bionatural extract A, results analysis shows that carbon steel resistance polarization as well as extract efficiency increase proportionally with increase in concentration of extract injected to achieve $1.485 \mathrm{kOhm} . \mathrm{cm}^{2}$ and an efficiency of $86.20 \%$ at $5 \mathrm{ppm}$. By injecting $30 \mathrm{ppm}$ of extract, corrosion rate is $0.048 \mathrm{~mm} /$ year was recorded and the processing efficiency reached $96.65 \%$.

Concerning the bionatural extract $\mathrm{B}$, the values of polarization resistance obtained from results exploitation of current intensities $O C P=f(I)$ of system (injection water and chemical species of bionatural extract B extracted from red algae Gymnogongrus crenulatus at different concentrations in contact with carbon steel API5LX60 are reported in the Table 7.

Table 7. Electrochemical parameters obtained by LRP technique of carbon steel immersed in an untreated medium and treated one with bionatural extract B

\begin{tabular}{|c|c|c|c|c|c|}
\hline $\begin{array}{c}\text { Concentration of } \\
\text { bionatural extract B } \\
(\mathrm{ppm})\end{array}$ & $\begin{array}{c}\text { OCP } \\
(\mathrm{V} / \mathrm{ECS})\end{array}$ & $\begin{array}{c}\mathrm{LRP} \\
\left(\mathrm{K} \Omega . \mathrm{cm}^{2}\right)\end{array}$ & $\begin{array}{c}\text { ICorr } \\
\left(\mu \mathrm{A} / \mathrm{cm}^{-2}\right)\end{array}$ & $\begin{array}{c}\text { CR } \\
(\mathrm{mm} / \mathrm{year})\end{array}$ & $\begin{array}{c}\text { Efficiency } \\
(\%)\end{array}$ \\
\hline 0 & -0.735 & 0.205 & 105.481 & 2.088 & $/$ \\
\hline 5 & -0.660 & 67.230 & 0.322 & 0.0064 & 99.69 \\
\hline 10 & -0.677 & 67.365 & 0.321 & 0.0064 & 99.69 \\
\hline 15 & -0.667 & 67.500 & 0.343 & 0.006 & 99.69 \\
\hline 20 & -0.677 & 68.850 & 0.343 & 0.006 & 99.70 \\
\hline 30 & -0.670 & 71.830 & 0.302 & 0.0059 & 99.71 \\
\hline 50 & -0.533 & 73.899 & 0.293 & 0.0058 & 99.72 \\
\hline
\end{tabular}

From results in Table 7, it was found that injection of bionatural extract B gave an excellent efficiency as its concentration in solution contaminated by SRB increased, at 5ppm efficiency exceeds $99 \%$ $(99.69 \%)$ and at $30 \mathrm{ppm}$ the efficiency increases again to reach $99.71 \%$. These values are followed by high polarization resistances of carbon steel and by low corrosion rates $(0.005 \mathrm{~mm} / \mathrm{year})$. Low corrosion

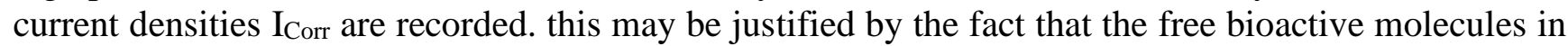
the solution tend to adsorb on steel surface, consequently, the increase in covering of protective film on 
surface of steel against biocorrosion prevents the passage of current which activates oxidation-reduction reactions, hence the blocking of corrosion phenomenon in general and of biocorrosion in particular.

So, the bionatural extract $\mathrm{C}$, the values of polarization resistance obtained from results exploitation of current intensities $O C P=f(I)$ of system (injection water and chemical species of bionatural extract $\mathrm{C}$ obtained from the red alga Pterocladia capillacea at different concentrations in contact with carbon steel API5LX60 are reported in the Table 8. It can be seen that polarization resistance of carbon steel immersed in injection water contaminated with SRB is low; it is $0.205 \mathrm{~K} \Omega . \mathrm{cm}^{2}$ that corresponds to 2.088 $\mathrm{mm} /$ year. After injection bionatural extract $\mathrm{C}$ at different concentrations, an increase in polarization resistance of steel was recorded as well as inhibitory efficiency which is proportional with increase of concentration to reach a resistance of $7.801 \mathrm{k} \Omega . \mathrm{cm}^{2}$ And an efficiency of $97.37 \%$ at $5 \mathrm{ppm}$. That confirms protective layer formation on steel surface. By increasing the concentration of extract, protective film becomes more important this is confirmed by recording of the values of resistances of polarization which reaches $22.917 \mathrm{~K} \Omega . \mathrm{cm}^{2}$ and a protective efficiency of $99.10 \%$ (Table 8).

Table 8. Electrochemical parameters obtained by lrp technique of carbon steel immersed in an untreated medium and treated one with bionatural Extract $\mathrm{C}$

\begin{tabular}{|c|c|c|c|c|c|}
\hline $\begin{array}{c}\text { Concentration of } \\
\text { bionatural extract C } \\
(\mathrm{ppm})\end{array}$ & $\begin{array}{c}\text { OCP } \\
(\mathrm{V} / \mathrm{ECS})\end{array}$ & $\begin{array}{c}\text { LRP } \\
\left(\mathrm{K} \Omega . \mathrm{Cm}^{2}\right)\end{array}$ & $\begin{array}{c}\text { I corr } \\
\left(\mu \mathrm{A} / \mathrm{Cm}^{-2}\right)\end{array}$ & $\begin{array}{c}\text { CR } \\
(\mathrm{mm} / \text { year })\end{array}$ & $\begin{array}{c}\text { Efficiency } \\
(\%)\end{array}$ \\
\hline 0 & -0.735 & 0.205 & 105.185 & 2.088 & - \\
\hline 5 & -0.677 & 7.801 & 2.782 & 0.055 & 97.37 \\
\hline 10 & -0.671 & 9.360 & 2.319 & 0.032 & 97.80 \\
\hline 15 & -0.654 & 13.482 & 1.610 & 0.031 & 98.48 \\
\hline 20 & -0.656 & 15.822 & 1.372 & 0.027 & 98.70 \\
\hline 30 & -0.644 & 20.128 & 1.053 & 0.026 & 98.98 \\
\hline 50 & -0.633 & 22.917 & 0.824 & 0.018 & 99.10 \\
\hline
\end{tabular}

Regarding the use of electrochemical impedance spectroscopy (EIS), this technique showed that when carbon steel is immersed in water inoculated with SRB, the metal surface is covered with a biofilm of microorganisms. Thus, the biofilm formed affects the transfer of charge and alters corrosion process of steel. EIS measurements have been carried out to monitor its formation and its evolution. This technique makes it possible to dissociate different steps of interfacial process, by separate evidencing values of ohmic resistance of electrolyte $\left(R_{e}\right)$ from charge transfer resistance $\left(R_{c t}\right)$, it also makes possible to calculate differential capacitances of electrical double layer $\left(\mathrm{C}_{\mathrm{dl}}\right)$ [22]. The results are generally represented by Nyquist and Bode diagrams, the response of an interface formed diameter of second semicircle is $\mathrm{R}_{\text {ct. }}$. The first characteristic is biofilm and second characterizes corrosion processes of metal [23].

When we used the extract A and based on Figure 9, we found out that semicircle impedance diagram characterizes carbon steel corrosion control by charge transfer process. $R_{e}$ was low for solution inoculated by SRB and not treated by bionatural extract A, according to impedance parameters given in Table 9, an increase in $R_{c t}$ and a decrease in electrical $C_{d l}$ values as a function of increase in concentration of bionatural treatment extract. These results allow us to conclude that extract A inhibits process of carbon steel biocorrosion by adsorption mechanism. It is also noted that $\mathrm{C}_{\mathrm{dl}}$ is inversely proportional to $\mathrm{R}_{\mathrm{p}}$ calculated previously. Higher resistance of material, the greater formation of protective film on metal surface, and more electronic ion-exchanging cloud (anions, cations). $\mathrm{C}_{\mathrm{dl}}$ was between $10^{-5}$ and $10^{-6}$ Farad $/ \mathrm{cm}^{2}$. The biomolecule inhibitory action by adsorption mechanism on metal surface is advanced. Certainly, more extract A was adsorbed to the surface, capacity of double layer was lower. 
When we used the extract $B$ and based on Figure 10 and from values of impedance parameters given in Table 10, we noted an increase in $R_{t c}$ and a decrease in $C_{d l}$ values as a function of the increase in concentration of bionatural extract $\mathrm{B}$. These results allow us to conclude that biocorrosion inhibition process is associated with the adsorption of molecules of algae extract on steel surface indicated by phase angle $\Theta$. The maximum phase angle values were is $-40^{\circ}$ and $-42^{\circ}$ at $5 \mathrm{ppm}$ and at $20 \mathrm{ppm}$ concentrations respectively, with respect to the doses of $10 \mathrm{ppm}, 15 \mathrm{ppm}, 30 \mathrm{ppm}$ and $50 \mathrm{ppm}$ the scanning of material surface was performed by two angles phase, which confirms presence of protective film of bionatural extract B on steel surface.

Table 9. Electrochemical parameters obtained by eis technique of carbon

\begin{tabular}{|c|c|c|c|c|c|c|c|}
\hline $\begin{array}{c}\text { Concentrations } \\
(\mathrm{ppm}) \\
\text { Parameters }\end{array}$ & 0 & 5 & 10 & 15 & 20 & 30 & 50 \\
\hline OCP $(\mathrm{V} / \mathrm{ECS})$ & -0.735 & -0.749 & -0.754 & -0.759 & -0.660 & -0.672 & -0.675 \\
\hline $\mathrm{R}_{\mathrm{s}}\left(\mathrm{k} . \Omega \mathrm{Cm}^{2}\right)$ & 0.02 & 0.13 & 0.09 & 0.09 & 0.12 & 0.12 & 0.04 \\
\hline $\mathrm{R}_{\mathrm{tc}}\left(\mathrm{k} . \Omega \mathrm{Cm}^{2}\right)$ & 0.25 & 1.04 & 1.85 & 2.10 & 3.52 & 5.44 & 7.20 \\
\hline $\mathrm{R}_{\mathrm{p}}\left(\mathrm{k} . \Omega \mathrm{Cm}^{2}\right)$ & 0.27 & 1.17 & 1.94 & 2.19 & 3.64 & 5.56 & 7.24 \\
\hline $\mathrm{C}_{\mathrm{dl}}\left(\mu \mathrm{F} / \mathrm{Cm}^{2}\right)$ & 200 & 40.50 & 40.50 & 2.92 & 2.98 & 2.98 & 1100 \\
\hline $\begin{array}{c}\text { Maximum phase } \\
\text { Angle } \Theta(\mathrm{deg})\end{array}$ & $-8^{\circ}$ & $-24^{\circ}$ & $-51^{\circ}$ & $-53^{\circ}$ & $-48^{\circ}$ & $-48^{\circ}$ & $-44^{\circ}$ \\
\hline Efficiency $(\%)$ & $/$ & 76.877 & 86.06 & 87.60 & 92.55 & 95.13 & 96.26 \\
\hline
\end{tabular}

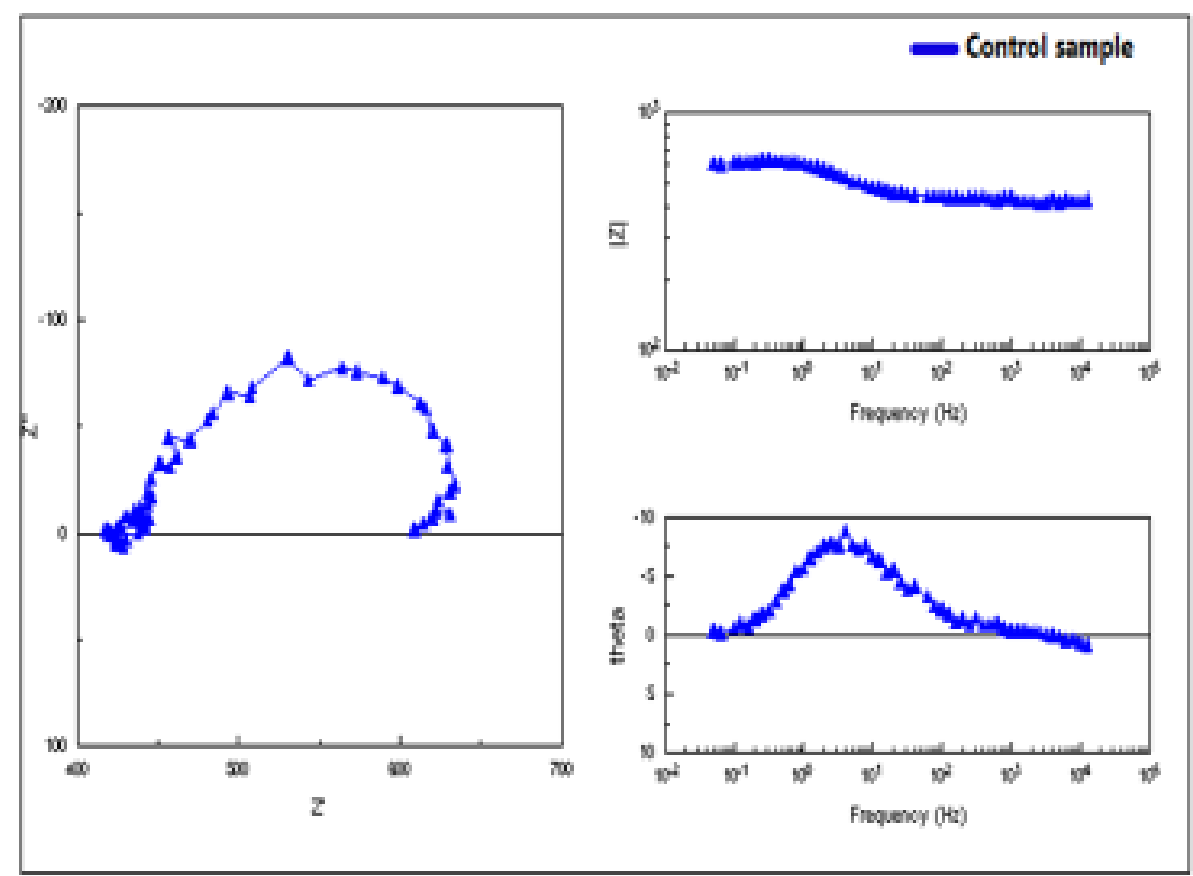




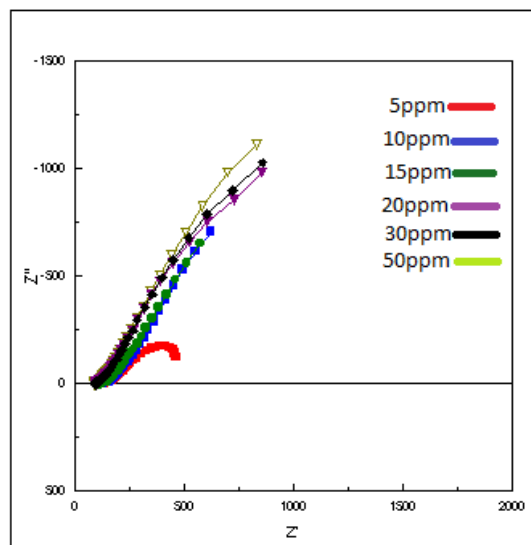

a. Diagram of Nyquist
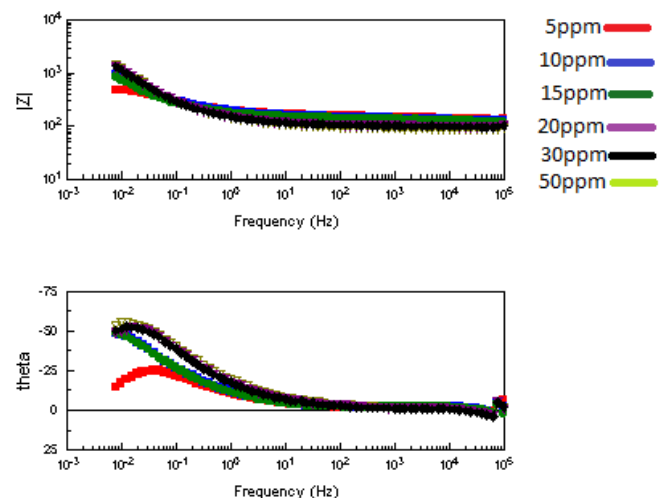

b. Diagram of Bode

Figure 9. Nyquist diagram and Bode diagram of carbon steel immersed in injection water contaminated with SRB, treated and untreated by bionatural extract $\mathrm{A}$

Table 10. Electrochemical parameters obtained by eis technique of carbon steel immersed in an untreated medium and treated one with bionatural extract B at different concentrations

\begin{tabular}{|c|c|c|c|c|c|c|c|}
\hline $\begin{array}{c}\text { Concentrations ppm } \\
\text { Parameters }\end{array}$ & 0 & 5 & 10 & 15 & 20 & 30 & 50 \\
\hline$(\mathrm{V} / \mathrm{ECS})$ & -0.735 & -0.830 & -0.667 & -0.649 & -0.656 & -0.660 & -0.649 \\
\hline $\mathrm{R}_{\mathrm{s}}\left(\mathrm{k} \Omega \cdot \mathrm{Cm}^{2}\right)$ & 0.02 & 0.29 & 0.27 & 0.26 & 0.27 & 0.26 & 0.23 \\
\hline $\mathrm{R}_{\mathrm{tc}}\left(\mathrm{k} \Omega \cdot \mathrm{Cm}^{2}\right)$ & 0.25 & 40.25 & 50.66 & 51.25 & 51.33 & 52.42 & 53.15 \\
\hline $\mathrm{R}_{\mathrm{p}}\left(\mathrm{k} \Omega \cdot \mathrm{Cm}^{2}\right)$ & 0.27 & 40.55 & 50.93 & 51.51 & 51.60 & 52.68 & 53.37 \\
\hline $\mathrm{C}_{\mathfrak{d}}\left(\mu \mathrm{F} / \mathrm{Cm}^{2}\right)$ & 210 & 140 & 79 & 76.8 & 74.2 & 80.5 & 71.5 \\
\hline $\begin{array}{c}\text { Maximum phase } \\
\text { Angle } \Theta(\mathrm{deg})\end{array}$ & $-8^{\circ}$ & $-40^{\circ}$ & $-41^{\circ} ;-44^{\circ}$ & $-44^{\circ} ;-41^{\circ}$ & $-42^{\circ}$ & $-44^{\circ} ;-42^{\circ}$ & $-45^{\circ} ;-42^{\circ}$ \\
\hline Efficiency $(\%)$ & $/$ & 99.33 & 99.46 & 99.47 & 99.47 & 99.48 & 99.49 \\
\hline
\end{tabular}
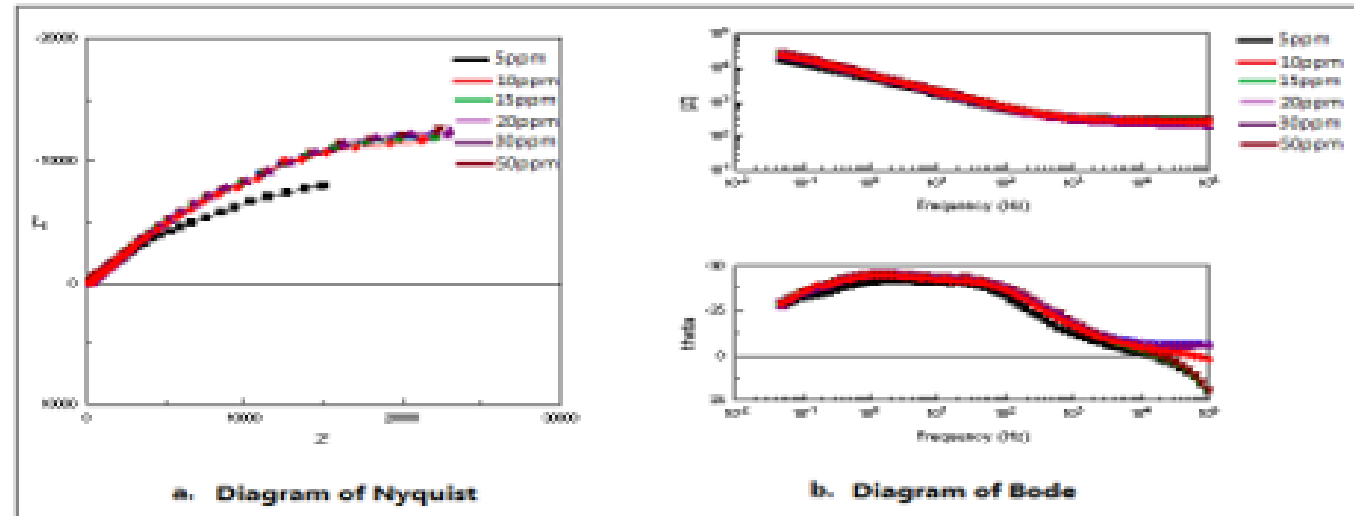

Figure 10. Nyquist diagram and Bode diagram of carbon steel immersed in injection water contaminated with SRB, treated and untreated

by bionatural extract $\mathrm{B}$

Concerning the bionatural extract $\mathrm{C}$, based on impedance parameters given in Table 11 and shown on Figure 11, we noted an increase in $R_{c t}$ and a decrease in $C_{d l}$ values as a function of increase in concentration of bionatural extract $\mathrm{C}$. These results allow us to announce that our algae extract inhibits biocorrosion process of carbon steel by adsorption mechanism. $C_{\mathrm{dl}}$ is inversely proportional to $\mathrm{R}_{\mathrm{p}}$. 
Higher resistance of material gives as, the more $C_{\mathrm{dl}}$ decreases until values of $10^{-5} \mathrm{Farad} / \mathrm{cm}^{2}$ are obtained. Inhibitory action of biomolecule by adsorption mechanism on metal surface was confirmed.

Table 11. Electrochemical parameters obtained by eis technique of carbon steel immersed in an untreated medium and treated one with bionatural extract $\mathrm{c}$ at different concentrations

\begin{tabular}{|c|c|c|c|c|c|c|c|}
\hline $\begin{array}{c}\text { Concentrations ppm } \\
\text { Parameters }\end{array}$ & 0 & 5 & 10 & 15 & 20 & 30 & 50 \\
\hline OCP $(\mathrm{V} / \mathrm{ECS})$ & -0.735 & -0.961 & -0.958 & -0.936 & -0.956 & -0.937 & -0.941 \\
\hline $\mathrm{R}_{\mathrm{s}}\left(\mathrm{k} \Omega \cdot \mathrm{Cm}^{2}\right)$ & 0.02 & 0.09 & 0.10 & 0.04 & 0.10 & 0.10 & 0.10 \\
\hline $\mathrm{R}_{\mathrm{tc}}\left(\mathrm{k} \Omega \cdot \mathrm{Cm}^{2}\right)$ & 0.25 & 5.47 & 6.10 & 10.39 & 11.01 & 14.14 & 14.31 \\
\hline $\mathrm{R}_{\mathrm{p}}\left(\mathrm{k} \Omega \cdot \mathrm{Cm}^{2}\right)$ & 0.27 & 5.56 & 6.20 & 10.43 & 11.11 & 14.24 & 14.41 \\
\hline $\mathrm{C}_{\mathrm{dl}}\left(\mu \mathrm{F} / \mathrm{Cm}^{2}\right)$ & 210 & 4100 & 800 & 300 & 300 & 300 & 26 \\
\hline $\begin{array}{c}\text { Maximum phase } \\
\text { Angle } \Theta(\mathrm{deg})\end{array}$ & $-8^{\circ}$ & $-38^{\circ}$ & $-46^{\circ}$ & $-63^{\circ}$ & $-52^{\circ}$ & $-50^{\circ}$ & $-48^{\circ}$ \\
\hline Efficiency $(\%)$ & $/$ & 95.13 & 95.63 & 97.40 & 97.56 & 98.09 & 98.12 \\
\hline
\end{tabular}

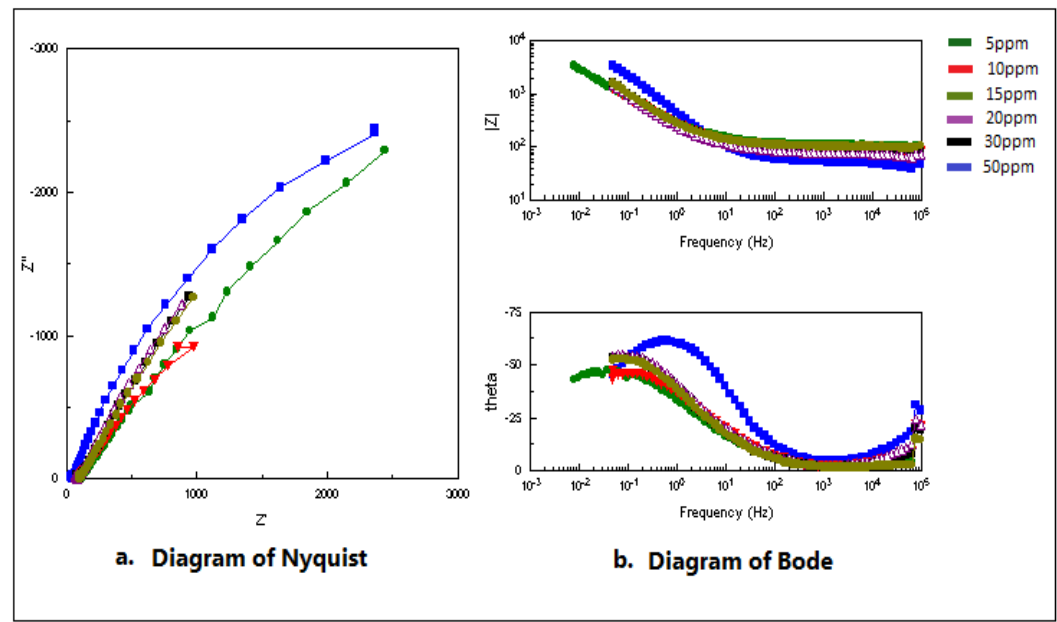

Figure 11. Nyquist diagram and Bode diagram of carbon steel immersed in injection water contaminated with SRB, treated and untreated by bionatural extract C

\section{Conclusions}

We studied inhibition efficiency treatment of biocorrosion with natural extracts from three species of marine red algae that we identified: Corallina elongata, Gymnogongrus crenulatus and Pterocladia capillacea. The ethanol extracts were tested as corrosion inhibitors on carbon steel immersed in injection water contaminated with sulfato-reducing bacteria (SRB). Infrared spectra of three extracts from red algae confirmed the presence of molecules, which contain amine functional groups (trimethylamines) that act as inhibitors of bacterial corrosion by their protective properties. The physicochemical analyzes of injection water showed that it is rich in nutriments such as carbon, sulfur, magnesium that are essential for bacterial development. The microbiological analysis of this water revealed $10^{2}$ germs $/ \mathrm{mL}$ of SRB concentration. Corrosion rate was firstly determined by weight loss method. The data have shown that the active substance extracted from red algae Gymnogongrus crenulatus has a higher bactericidal power over corrosion caused by SRB, more active than the extracts from Corallina elongata and Pterocladia capillacea. SEM and metallographic observations have confirmed the presence of protective layer formed on steel surface.

The use of electrochemical techniques (OCP-time, LPR and EIS) permitted to determine various electrochemical parameters (corrosion current density, corrosion rate, polarization resistance, inhibition efficiency, electrolyte resistance, charge transfer resistance, double layer capacity of protective film), these results making possible to evaluate protection properties of bionatural extracts. The shift of 
corrosion potential to electropositive values with increased extract concentration in electrolyte indicates the inhibition ability of each extract. Electrochemical impedance diagrams showed Nyquist semicircles which increase their diameter proportionally with extract concentration. Similarly, the values of charge transfer $\mathrm{R}_{\mathrm{ct}}$ were comparable to $\mathrm{R}_{\mathrm{P}}$ obtained from LRP techniques. Thus, both resistances represent the ability of steel surface to prevent flow of current into the medium. The electrochemical data showed an increase in protective power and a decrease in corrosion rate as extract concentration increased. The extract from Gymnogongrus crenulatus has given a very effective protection to stop carbon steel corrosion. By comparing our results with previous works we deduced that bionaturels algae extracts have a good anticorrosive effect and can have their place in the petroleum industry.

\section{References}

1. CROLET, J.L., DAUMAS, S., MAGOT, M., $p H$ regulation by sulfate-reducing bacteria, 'Corrosion 93' Proceedings, Sept. 19-24, 1993, Houston, TX, Natl. Assoc. of Corrosion Engineers, paper 303.

2.AUDISIO, S., BERANGER, G., Anticorrosion et durabilité dans le bâtiment, le génie civil et les ouvrages industriels, Presses polytechniques et universitaires romandes, Lausanne, 2010.

3. POSTGATE, J.R., The Sulfate-Reducing Bacteria, Cambridge University Press, Cambridge, UK, 1979, 148-155.

4.LEE, W., LEWANDOWSKI, Z., NIELSEN, P.H., HAMILTON, W.A., Role of sulfate-reducing bacteria in corrosion of mild steel: A review, Biofouling, 8(3), 1995, 165-194.

5. PEREZ, R., Ces algues qui nous entourent: conception actuelle, rôle dans la biosphère, utilisations, culture, Editions Quae, Versailles, 1997, 24-25.

6.YOON, H.S., MÜLLER, K.M., SHEATH, R.G., OTT, F.D., BHATTACHARYA, D., Defining the major lineages of red algae (Rhodophyta), J. Phycol., 42, 2006, 482-492.

7.CLARKE, K.R., WARWICK, R.M., Change in Marine Communities: An Approach to Statistical Analysis and Interpretation, PRIMER-E Ltd, Plymouth, UK, 2001, 120-132

8ANGELL, S., BENCH, B.J., WILLIAMS, H., WATANABE, C.M.H., Pyocyanin isolated from a marine microbial population: Synergistic production between two distinct bacterial species and mode of action, Chemistry \& Biology, 13, 2006, 1349-1359.

9. COUTO, R.P., ROSAS-ALQUICIRA, E.F., RODRIGUES, A.S., NETO, A.I., The genus Ellisolandia (Corallinaceae, Corallinales, Rhodophyta) in the Azores (NE Atlantic): character expression and taxonomic evaluation, Phytotaxa, 190(1), 2014, 5-16.

10. SANTELICES, B., HOMMERSAND, M., Pterocladiella, a new genus in the Gelidiaceae (Gelidiales, Rhodophyta), Phycologia, 36(2), 1997, 114-119

11.DIMO, T., NGUELEFACK, T.B., KAMTCHOUING, P., DONGO, E., RAKOTONIRINA, A., RAKOTONIRINA, S.V., Hypotensive effects of a methanol extract of Bidens pilosa Linn on hypertensive rats, C. R. Acad. Sci. 322(4), 1999, 323-329.

12.***Standard Recommended Practice Preparation, Installation, Analysis, and Interpretation of Corrosion Coupons in Oilfield Operations, NACE Standard, Houston, RP0775, 1999. 21017, 5-15.

13.***Standard Test Method for Corrosivity of Water in the Absence of Heat Transfer (Weight Loss Methods), ASTM D2688 - 05.

14. LANDOLT, D., Corrosion and Surface Chemistry of Metals, CRC Press, Boca Raton, FL, 2007

15. ENNING, D., GARRELFS, J., Corrosion of iron by sulfate-reducing bacteria: New views of an old problem, Applied and Environmental Microbiology, 80(4), 2014, 1226-1236.

16.BALAKRISHNAN A., RANI, P.G., SUNDARAM M., NATARAJAN P., UTHANDI K.M., Corrosion characteristics of sulfate-reducing bacteria (SRB) and the role of molecular biology in SRB studies: An overview, Corrosion Reviews, 34(1-2), 2016, 41-63.

17.CHEN, J., WU, J., WANG, P., ZHANG, D., CHEN, S., TAN, F., Corrosion of 907 steel influenced by sulfate-reducing bacteria, J. Mater. Eng. Perform., 28, 2019, 1469-1479.

18.CHARACKLIS, W.G., COOKSEY, K.E., Biofilms and microbial fouling, Adv. Appl. Microbiol., 29, 1983, 93-138. 
19.STALEY, J.T., GUNSALUS, R.P., LORY, S., PERRY, J.J., Microbial Life, (Second ed.), Sinauer Associates, Sunderland, MA, 2007.

20.CORDONNIER, J., Suez Lyonnaise des Eaux, CIRSEE, Le Pecq, France, 1996, 1-10.

21.JONES, D.A., AMY, P.S., Related electrochemical characteristics of microbial metabolism and iron corrosion, Ind. Eng. Chem. Res., 39, 2000, 575-582.

22.RANDVIIR, E.P., BANKS, C.E., Electrochemical impedance spectroscopy: an overview of bioanalytical applications, Analytical Methods, 5, 2013, 1098-1115.

23.HERNÁNDEZ, H.H., REYNOSO, A.M.R., GONZÁLEZ, J.C.T., MORÁN, C.O.G., HERNÁNDEZ, J.G.M., RUIZ, A.M., HERNÁNDEZ, J.M., CRUZ, R.O., Electrochemical impedance spectroscopy (EIS): A review study of basic aspects of the corrosion mechanism applied to steels, in: Electrochemical Impedance Spectroscopy, EL-AZAZY, M., MIN, M., ANNUS, P. (Eds.), IntechOpen, Rijeka, 2020.

Manuscript received: 09.09.2020 